\title{
Gene expression in human small intestinal mucosa in vivo is mediated by iron-induced oxidative stress
}

Citation for published version (APA):

Troost, F. J., Brummer, R. J., Haenen, G. R., Bast, A., van Haaften, R. I. M., Evelo, C. T., \& Saris, W. H. (2006). Gene expression in human small intestinal mucosa in vivo is mediated by iron-induced oxidative stress. Physiological genomics, 25(2), 242-249. https://doi.org/10.1152/physiolgenomics.00114.2005

Document status and date:

Published: 01/01/2006

DOI:

10.1152/physiolgenomics.00114.2005

Document Version:

Publisher's PDF, also known as Version of record

Document license:

Taverne

Please check the document version of this publication:

- A submitted manuscript is the version of the article upon submission and before peer-review. There can be important differences between the submitted version and the official published version of record.

People interested in the research are advised to contact the author for the final version of the publication, or visit the DOI to the publisher's website.

- The final author version and the galley proof are versions of the publication after peer review.

- The final published version features the final layout of the paper including the volume, issue and page numbers.

Link to publication

\footnotetext{
General rights rights.

- You may freely distribute the URL identifying the publication in the public portal. please follow below link for the End User Agreement:

www.umlib.nl/taverne-license

Take down policy

If you believe that this document breaches copyright please contact us at:

repository@maastrichtuniversity.nl

providing details and we will investigate your claim.
}

Copyright and moral rights for the publications made accessible in the public portal are retained by the authors and/or other copyright owners and it is a condition of accessing publications that users recognise and abide by the legal requirements associated with these

- Users may download and print one copy of any publication from the public portal for the purpose of private study or research.

- You may not further distribute the material or use it for any profit-making activity or commercial gain

If the publication is distributed under the terms of Article $25 \mathrm{fa}$ of the Dutch Copyright Act, indicated by the "Taverne" license above, 


\title{
Gene expression in human small intestinal mucosa in vivo is mediated by iron-induced oxidative stress
}

\author{
Freddy J. Troost, ${ }^{1}$ Robert-Jan M. Brummer, ${ }^{2}$ Guido R. M. M. Haenen, ${ }^{3}$ \\ Aalt Bast, ${ }^{3}$ Rachel I. van Haaften, ${ }^{4}$ Chris T. Evelo, ${ }^{4}$ and Wim H. M. Saris ${ }^{5}$ \\ ${ }^{1}$ Department of Internal Medicine/Gastroenterology, Maastricht University; ${ }^{2}$ Departments of Internal Medicine/ \\ Gastroenterology and Clinical Dietetics, University Hospital Maastricht; ${ }^{3}$ Department of Pharmacology, Maastricht \\ University; ${ }^{4}$ BioInformatics Group CARIM and TU Eindhoven (BiGCAT Bioinformatics), and ${ }^{5}$ Department of Human Biology, \\ Maastricht University, all Nutrition and Toxicology Research Institute Maastricht (NUTRIM), Maastricht, The Netherlands
}

Submitted 12 May 2005; accepted in final form 31 January 2006

Troost, Freddy J., Robert-Jan M. Brummer, Guido R. M. M. Haenen, Aalt Bast, Rachel I. van Haaften, Chris T. Evelo, and Wim H. M. Saris. Gene expression in human small intestinal mucosa in vivo is mediated by iron-induced oxidative stress. Physiol Genomics 25: 242-249, 2006. First published February 7, 2006; doi:10.1152/physiolgenomics.00114.2005.-Iron-induced oxidative stress in the small intestine may alter gene expression in the intestinal mucosa. The present study aimed to determine which genes are mediated by an iron-induced oxidative challenge in the human small intestine. Eight healthy volunteers $[22 \mathrm{yr}(\mathrm{SD} 2)]$ were tested on two separate occasions in a randomized crossover design. After duodenal tissue sampling by gastroduodenoscopy, a perfusion catheter was inserted orogastrically to perfuse a $40-\mathrm{cm}$ segment of the proximal small intestine with saline and, subsequently, with either 80 or $400 \mathrm{mg}$ of iron as ferrous gluconate. After the intestinal perfusion, a second duodenal tissue sample was obtained. Thiobarbituric acid-reactive substances, an indicator of lipid peroxidation, in intestinal fluid samples increased significantly and dose dependently at $30 \mathrm{~min}$ after the start of perfusion with 80 or $400 \mathrm{mg}$ of iron, respectively $(P<$ $0.001)$. During the perfusion with $400 \mathrm{mg}$ of iron, the increase in thiobarbituric acid-reactive substances was accompanied by a significant, momentary rise in trolox equivalent antioxidant capacity, an indicator of total antioxidant capacity $(P<0.05)$. The expression of 89 gene reporters was significantly altered by both iron interventions. Functional mapping showed that both iron dosages mediated six distinct processes. Three of those processes involved G-protein receptor coupled pathways. The other processes were associated with cell cycle, complement activation, and calcium channels. Iron administration in the small intestine induced dose-dependent lipid peroxidation and a momentary antioxidant response in the lumen, mediated the expression of at least 89 individual gene reporters, and affected at least six biological processes.

transcriptomics; intestine; epithelium; microarrays

IT IS GENERALLY ACCEPTED THAT Oxidative stress in the intestine is an etiological factor in the pathophysiology of several inflammation-associated disorders, such as inflammatory bowel disease and celiac disease $(11,15-17,28)$. Diet-related components may be important mediators of oxidative damage. Previous studies $(9,21)$ showed that iron supplements induce oxidative damage to the small intestine, owing to its catalyzing role in Fenton chemistry, which results in the production of highly reactive hydroxyl radicals. Furthermore, iron intake was

Article published online before print. See web site for date of publication (http://physiolgenomics.physiology.org).

Address for reprint requests and other correspondence: F. J. Troost, Dept. of Gastroenterology, NUTRIM, Maastricht Univ., PO Box 616, 6200 MD Maastricht, The Netherlands (e-mail: f.troost@intmed.unimaas.nl). associated with impairment of the barrier function of the small intestine epithelium (14), the development of inflammation in ulcerative colitis $(1,19)$, a decrease in cell turnover, shortening of microvillus height and erosions of the microvilli in the duodenum (22), and the development of colon cancer $(20,26)$. Our laboratory showed previously that a single iron dose administered directly into the small intestine induces lipid peroxidation and the release of, yet unidentified, antioxidants in the lumen of the small intestine (24). The cellular mechanisms involved in the intestinal oxidative stress and defence responses are not clear. The rapidly evolving microarray technology provides a sophisticated method to synchronously monitor the expression of thousands of genes to obtain information about the regulation of numerous biochemical processes in the intestinal mucosa on the transcriptional level. This technique has the potential to elucidate complex biochemical or physiological pathways, such as intestinal oxidative stress and its consequences. The combination of the microarray technology with novel, invasive human intervention models, applied in the present study, provides a unique and valuable tool to investigate nutrient-gene interactions in vivo in the human intestine.

The present study aimed to assess iron-induced oxidative damage and the antioxidant response in the human small intestine in vivo after administration of commonly used iron substitution dosages and to determine the effects of this intestinal oxidative stress on transcriptome profiles in the small intestine.

\section{MATERIALS AND METHODS}

\section{Subjects}

Eight healthy nonsmoking volunteers [22 yr(SD2), 7 men, 1 woman] without a history of gastrointestinal disorders participated in the study. Volunteers were free of medication and in good physical health. All subjects gave their written, informed consent before participation. The study protocol was approved by the Ethics Committee of the University Hospital Maastricht, Maastricht, The Netherlands.

\section{Protocol}

This study was designed to conform to a randomized crossover design. Each subject was tested on 2 separate days. On each test day, tissue samples from the duodenum were obtained before and after small intestinal perfusion experiments. On each day, one iron dosage was administered directly into the duodenum through a perfusion catheter, as described below. In the intestinal perfusion experiments, intestinal fluid samples were obtained at 15-min intervals during saline perfusion as baseline samples and during the subsequent iron perfusion. 
After an overnight fast, baseline duodenal biopsies, taken by standard forceps in the proximal horizontal part of the duodenum (15 $\mathrm{cm}$ distally from the pylorus), were obtained by gastroduodenoscopy. All gastroduodenoscopies were performed without giving any kind of sedatives to the subjects. Biopsies were imbedded in tissue-tek (Electron Microscopy Sciences, Washington, PA), snap-frozen in melting isopentane and liquid nitrogen, respectively, and stored at $-80^{\circ} \mathrm{C}$ until analysis. After obtaining the mucosal samples, a guide wire was inserted with the distal tip positioned about $60 \mathrm{~cm}$ distally from the pylorus, facilitated by the duodenoscopy. After retraction of the endoscope, a double lumen perfusion catheter (home made from PVC tubing, inner diameter $2.5 \mathrm{~mm}$, outer diameter $4 \mathrm{~mm}$ ) was inserted over the guide wire into the proximal small intestine with the tip of one lumen, which served as an injection port, located in the proximal descending duodenum and the tip of the second lumen, with three small holes in the last $3 \mathrm{~cm}$ to serve as a sample port, located $40 \mathrm{~cm}$ distally from the injection port. After being positioned, the guide wire was removed. The whole procedure was performed under shortinterval fluoroscopic control. To check positioning of the injection port in the duodenum throughout the experiment, intraluminal $\mathrm{pH}$ was continuously measured at $5 \mathrm{~cm}$ proximal of the injection port by a $\mathrm{pH}$ electrode (Single Crystal Antimony Multi-Use pH Catheter, Synectics Medical, Queluz, Portugal). The 40-cm segment of the proximal small intestine was perfused with saline at $10 \mathrm{ml} / \mathrm{min}$ using a peristaltic pump for $195 \mathrm{~min}$ to obtain steady-state conditions. After reaching steady state, either 80 or $400 \mathrm{mg}$ of iron as ferrous gluconate dissolved in $300 \mathrm{ml}$ saline was perfused. The iron solutions were perfused over a 30-min period. Finally, saline was perfused for another $60 \mathrm{~min}$. All in-going solutions were kept on $37^{\circ} \mathrm{C}$ in a water bath. Throughout the perfusion experiment, intestinal fluid samples were obtained continuously using the lever properties of the catheter. After the initial 180-min adaptation period, intestinal fluid was levered through the sample lumen into a beaker placed in melting ice. Intestinal fluids were pooled over 15 -min intervals and stored at $-80^{\circ} \mathrm{C}$ until analysis.

Fifteen minutes after the perfusion experiment, the perfusion catheter was removed and a second gastroduodenoscopy was performed to obtain tissue samples from the same intestinal region after the iron challenge. These tissue samples were obtained 3-4 cm distally from those taken in the morning. The exact position of the tissue sampling in the morning was achieved by visual inspection of the gut mucosa. A red color from the mucosa, different from the surrounding tissue, showed the exact position of earlier tissue sampling. The entire protocol was repeated on another day, $\sim 2$ wk after the first experiment, to investigate the effects of the other iron dosage. The administration of both dosages was in random order.

\section{Gene Expression Analysis}

Gene expression profiles were determined in all tissue samples. Histological staining was done in a subset of the samples to check the composition of the samples. The mucosal tissue samples contained epithelium from several intestinal villi and also lamina propria. Total RNA was isolated from each tissue sample, and RNA quality was assessed by SDS-PAGE gel electrophoresis. After quality check, only tissue samples from five subjects provided good-quality RNA. The tissue samples from three subjects were excluded from the microarray analyses. For budget reasons, the RNA samples from the remaining five subjects, all men, were randomly allocated to one of two pools. Samples from two subjects were pooled in pool 1, and samples from three subjects were pooled in pool 2. On each pooled sample, a microarray analysis to determine gene expression profiles was carried out. Samples were obtained before and immediately after the intestinal perfusion with a low or a high iron dosage, as described above.

\section{cRNA Preparation and In Vitro Transcription}

Ten micrograms of total RNA was used as starting material for the cDNA preparation. The first- and second-strand cDNA synthesis was performed using the SuperScript II System (Invitrogen) according to the manufacturers instructions except using an oligo-dT primer containing a T7 RNA polymerase promoter site. Labeled cRNA was prepared using the BioArray high-yield RNA transcript labeling kit (Enzo, Farmingdale, NY). Biotin-labeled CTP and UTP (Enzo) were used in the reaction together with unlabeled NTPs. After the in vitro transcription (IVT) reaction, the unincorporated nucleotides were removed using RNeasy columns (Qiagen).

\section{Array Hybridization and Scanning}

Fifteen micrograms of cRNA was fragmented at $94^{\circ} \mathrm{C}$ for $35 \mathrm{~min}$ in a fragmentation buffer containing (in $\mathrm{mM}$ ) 40 Tris-acetate $(\mathrm{pH} 8.1$ ), $100 \mathrm{KOAc}$, and $30 \mathrm{MgOAc}$. Before hybridization, the fragmented cRNA in a $\times 6$ SSPE-T hybridization buffer $[1 \mathrm{M} \mathrm{NaCl}, 10 \mathrm{mM}$ Tris (pH 7.6), $0.005 \%$ Triton] was heated to $94^{\circ} \mathrm{C}$ for $5 \mathrm{~min}$ and subsequently to $45^{\circ} \mathrm{C}$ for 5 min before loading onto the Affymetrix $\mathrm{HG}$ U133A probe array cartridge. The probe array was then incubated for $16 \mathrm{~h}$ at $45^{\circ} \mathrm{C}$ at constant rotation $(60 \mathrm{rpm})$. The washing and staining procedure was performed in the Affymetrix Fluidics Station. The probe array was exposed to 10 washes in $\times 6 \mathrm{SSPE}-\mathrm{T}$ at $25^{\circ} \mathrm{C}$ followed by 4 washes in $\times 0.5 \mathrm{SSPE}-\mathrm{T}$ at $50^{\circ} \mathrm{C}$. The biotinylated cRNA was stained with a streptavidin-phycoerythrin conjugate, final concentration $2 \mathrm{mg} / \mathrm{ml}$ (Molecular Probes, Eugene, OR) in $\times 6$ SSPE-T for $30 \mathrm{~min}$ at $25^{\circ} \mathrm{C}$, followed by 10 washes in $\times 6 \mathrm{SSPE}-\mathrm{T}$ at $25^{\circ} \mathrm{C}$. Subsequently, an antibody amplification step was performed, using normal goat $\mathrm{IgG}$ as blocking reagent, final concentration 0.1 $\mathrm{mg} / \mathrm{ml}$ (Sigma, Copenhagen, Denmark), and biotinylated anti-streptavidin antibody (goat) to obtain a final concentration of $3 \mathrm{mg} / \mathrm{ml}$ (Vector Laboratories, Burlingame, CA). This was followed by a staining step with a streptavidin-phycoerythrin conjugate, final concentration $2 \mathrm{mg} / \mathrm{ml}$ (Molecular Probes, Eugene, OR), in $\times 6$ SSPE-T for $30 \mathrm{~min}$ at $25^{\circ} \mathrm{C}$, and 10 washes in $\times 6 \mathrm{SSPE}-\mathrm{T}$ at $25^{\circ} \mathrm{C}$. The probe arrays were scanned at $560 \mathrm{~nm}$ using a confocal laser-scanning microscope (Hewlett Packard GeneArray scanner G2500A). The readings from the quantitative scanning were analyzed with the Affymetrix gene expression analysis software. All microarray data are publicly available on the ArrayExpress website, as described in RESULTS.

Each gene reporter on the U133A chip was represented by 11 pairs of 25-mer oligodeoxyribonucleotide probes. Each probe pair consists of a perfect-match oligonucleotide that precisely matches the gene sequence and a mismatch oligonucleotide that differs only in one single nucleotide mismatch in the center position. The data from the different sets of probe pairs were used to perform the statistical analyses. For comparison from array to array, all signal data from the quantitative readings were scaled to a global intensity of 150 , as previously published $(4,23)$.

The signal intensities from the microarrays were scaled and further analyzed using the Affymetrix Microarray Suite version 5.0 software (Affymetrix, Santa Clara, CA). Relative mRNA changes between microarrays were expressed as differences or delta compared with baseline samples for the 80- and 400-mg iron challenge, respectively. The definition of increase, decrease, or no change of expression for individual gene reporters was based on $P$ values of the comparisons of the normalized signal intensities, with $P<0.05$ as cutoff for change calls. Gene reporters that were either up- or downregulated in the same direction in both pools were further investigated. If the expression of a gene reporter was increased in one pool while it did not change or decrease in the other pool, it was assumed that the gene expression was not mediated by the iron interventions. Likewise, only those gene reporters that were mediated in the same direction by both the low- and the high-iron dosage interventions were further investigated.

To allow functional mapping of expression profiles, the annotation of individual probes with the Swissprot [http://us.expasy.org/sprot/ sprot-top.html (5)] database identification (ID) for the corresponding 
protein was used. Using these IDs, expression changes for each of the four pooled samples were studied using functional MicroArray pathway profiles (MAPPs) available from the GenMapp initiative (http:// www.genmapp.org/) with GenMapp version 1.0 beta software (7). MAPPs generated from the Gene Ontology database [http://www. geneontology.org/ (6)], the G-Protein Coupled Receptor Database (http://www.gpcr.org/), plus a small number of MAPPs based on the KEGG database (http://www.genome.ad.jp/kegg/) and MAPPs specifically designed for GenMapp (so called local MAPPs) were used. MappFinder software was used to select the MAPPs with relatively high numbers of differentially expressed gene reporters with a fold change of at least 2.3 , as was indicated by the individual Z-scores. The $\mathrm{Z}$-score increases when relatively higher numbers of changing gene reporters relative to the number of genes present on the MAPP that are represented on the array are found on MAPPs. MAPPs were selected for further study when all four samples reached an arbitrary Z-score of at least 1 on that MAPP.

Real-time PCR. To validate the observed mRNA changes from the microarray analyses, real-time PCR was performed on seven genes. cDNA was synthesized from single samples previously analyzed on GeneChips. The microarray gene reporter expression profiles of the seven genes, with Unigene cluster IDs nm_005410, nm_001924, nm_002306, nm_005118, nm_00075, nm_003355, and nm_003056, were compared with real-time PCR. For this purpose, real-time PCR measurements were done in the pooled samples that were also used for the microarray experiments. Additionally, real-time PCR analyses were carried out on all individual samples. Reverse transcription was performed using Superscript II RT (Invitrogen). $1 \mu \mathrm{g}$ of total RNA and $3 \mu \mathrm{l}$ of $150 \mathrm{pmol} / \mu \mathrm{l}$ random nonamer-primer in a total volume of $12 \mu \mathrm{l}$ was incubated $4 \mathrm{~min}$ at $70^{\circ} \mathrm{C}$ and chilled on ice. After adding 4 $\mu l$ of first-strand buffer (from supplier), $2 \mu \mathrm{l}$ of DTT $(0.1 \mathrm{M}), 1 \mu \mathrm{l}$ of dNTP mix $(10 \mathrm{mM})$, and $1 \mu \mathrm{l}$ of SuperScript RT II $(200 \mathrm{U} / \mu \mathrm{l})$, the reaction was incubated $1 \mathrm{~h}$ at $45^{\circ} \mathrm{C}$ and finally for $15 \mathrm{~min}$ at $70^{\circ} \mathrm{C}$. The cDNA was diluted 1:20 for use in real-time PCR. Real-time PCR analysis was performed on selected genes using primers, designed with PrimerExpress software from Applied Biosystems. Triple determinations were performed on ABI PRISM 7000 sequence detection system using the SYBR Green PCR Master Mix (Applied Biosystems). The PCR reaction consisted of $12.5 \mu$ l of SYBR Green PCR Master Mix, $300 \mathrm{nM}$ of forward and reverse primers, and $2.0 \mu \mathrm{l}$ of 1:20 diluted template cDNA in a total volume of $25 \mu l$. The reaction was thermocycled using the default settings of "ABI Prism 7000 SDS Software 1.0": $2 \mathrm{~min}$ at $50^{\circ} \mathrm{C}, 10 \mathrm{~min}$ at $95^{\circ} \mathrm{C}$, followed by 40 rounds of $15 \mathrm{~s} 95^{\circ} \mathrm{C}$ and $1 \mathrm{~min}$ at $60^{\circ} \mathrm{C}$. A dissociation protocol was added after thermocycling, determining dissociation of the PCR products from 65 to $95^{\circ} \mathrm{C}$. All samples were normalized to GAPDH, as was applied previously (4).

\section{Biochemical Analysis of Intestinal Fluid Samples}

Thiobarbituric acid-reactive substances assay. The determination of thiobarbituric acid-reactive substances (TBARS) was based on the formation of a coloured adduct of malondialdehyde with 2-thiobarbituric acid. A $100-\mu l$ sample was added to $900 \mu$ l of a reagent [containing $0.12 \mathrm{M}$ 2-thiobarbituric acid, $0.32 \mathrm{M} O$-phosphoric acid, $0.68 \mathrm{mM}$ butylated hydroxytoluene, and $0.01 \%$ (mass/vol) EDTA]. The mixture was incubated for $1 \mathrm{~h}$ at $100^{\circ} \mathrm{C}$ in a water bath. After cooling, the malondialdehyde products were extracted with $500 \mu \mathrm{l}$ of butanol. Thirty microliters of the butanol layer was injected on a HPLC system (Agilent, Palo Alto, CA), equipped with a fluorescence detector, set on excitation wavelength of $532 \mathrm{~nm}$ and emission wavelength of $553 \mathrm{~nm}$, and a Nucleosil C18 column, $150 \times 3.2 \mathrm{~mm}$, particle size $5 \mu \mathrm{m}$ (Supelco). Samples were eluted with $65 \%$ (vol/vol) $25 \mathrm{mM}$ phosphate buffer $\mathrm{pH} \mathrm{4.8,35 \%} \mathrm{(vol/vol)} \mathrm{methanol.} \mathrm{A} \mathrm{calibra-}$ tion curve was constructed using malonaldehyde bis(diethylacetal) as standard.
Antioxidant capacity assay. The antioxidant capacity assay was carried out as described previously (3) with some modifications. The 2,2'-azinobis(3-ethylbenzothiazoline 6-sulfonate) (ABTS) radical was produced by incubating a solution of $0.23 \mathrm{mM}$ ABTS and $2.3 \mathrm{mM}$ 2,2' -azobis(2-amidinopropane)dihydrochloride (ABAP) in $100 \mathrm{mM}$ sodium phosphate buffer $(\mathrm{pH} 7.4)$ at $70^{\circ} \mathrm{C}$ until the absorption of the solution at $734 \mathrm{~nm}$ was between 0.680 and 0.720 . Deproteination was obtained by mixing the sample with an equal volume of a solution of $10 \%(\mathrm{wt} / \mathrm{vol})$ trichloro-acetic acid. In the reaction of antioxidants with the blue/green ABTS radical, the blue-green color disappears. This decolorization after 5 min was determined spectrophotometrically at $734 \mathrm{~nm}$. The reduction in absorbance is related to that of trolox, a synthetic, hydrophilic vitamin $\mathrm{E}$ analog, which gives the troloxequivalent antioxidant capacity (TEAC) value. The TEAC value was calculated as molar trolox equivalents of the sample.

\section{Statistics}

Statistical analyses of the scaled microarray data were performed with the Affymetrix Microarray Suite version 5.0 software package, applying Wilcoxon's signed rank tests to detect differences between arrays. Time effects of malondialdehyde and TEAC within each iron intervention, compared with baseline values obtained at time $=0$, were investigated with repeated-measuresANOVA. Significant time differences were located with Scheffé's post hoc analyses, including Bonferroni correction for multiple comparisons. Univariate ANOVAs were used to assess differences between the two iron dosages. Differences were regarded as significant if $P<0.05$.

\section{RESULTS}

\section{Gene Expression}

All array data are publicly available on the ArrayExpress website (http://www.ebi.ac.uk/arrayexpress/) and can be accessed by logging in to the system with username "e-mexp325 " and password "6iud2ebi." After normalization of the microarray signals, 8,542 gene reporters showed a significant expression in both pools at baseline. Another 476 gene reporters were marginally expressed according to the Affymetrix default cutoff values, whereas the remaining 13,271 reporters were not expressed in the duodenal tissue samples.

The microarray analyses showed that the expressions of 89 gene reporters were consistently increased or decreased compared with baseline by both iron challenges in both pools; 28 gene reporters were increased (Table 1), whereas 61 gene reporters were decreased (Table 2).

Mapping the individual gene reporters to shared biological pathways using MAPPFinder software revealed that, considering the biological processes observed in both pools, six biological processes were mediated by both iron dosages. Three of those six processes involved G-protein-coupled receptors (GPCRs), whereas the other three processes were associated with complement activation, calcium channels, and cell cycle. The processes, which were mediated by the two interventions in both sample pools, are listed in Table 3. Table 3 shows the smallest number of gene reporters mediated by any pool in any intervention. Furthermore, it shows the number of gene reporters involved in each process, which were represented on the microarray chip, and the total number of genes involved in each process, which was defined by the databases described in METHODS.

Real-time PCR analyses of seven randomly selected genes showed good similarity with microarray analyses of the same genes, considering the direction of changes in gene reporter 
Table 1. Gene reporters consistently downregulated by perfusion of a small intestinal segment with 80 and $400 \mathrm{mg}$ of iron on 2 separate test days

\begin{tabular}{|c|c|}
\hline Probe ID & Gene Title \\
\hline 200617_at & KIAA0152 gene product \\
\hline 201009_s_at & Thioredoxin-interacting protein \\
\hline 201275_at & Farnesyl diphosphate synthase \\
\hline 201790_s_at & 7-dehydrocholesterol reductase \\
\hline 201876_at & Paraoxonase 2 \\
\hline 202017_at & Epoxide hydrolase 1, microsomal (xenobiotic) \\
\hline 202025_x_at & Acetyl-Coenzyme A acyltransferase 1 \\
\hline 202122_s_at & Mannose 6 phosphate receptor binding protein \\
\hline 202433_at & UDP-galactose transporter related \\
\hline \multicolumn{2}{|l|}{ 202793_at } \\
\hline 203414_at & Monocyte to macrophage differentiation-associated \\
\hline 203633_at & Carnitine palmitoyltransferase 1 , liver \\
\hline 203943_at & Kinesin family member $3 \mathrm{~B}$ \\
\hline 204039_at & CCAAT/enhancer binding protein $(\mathrm{C} / \mathrm{EBP})$, alpha \\
\hline 204233_s_at & Choline kinase \\
\hline 204266_s_at & Choline kinase \\
\hline 204429_s_at & $\begin{array}{l}\text { Solute carrier family } 2 \text { (facilitated glucose/fructose } \\
\text { transporter), } 5\end{array}$ \\
\hline 204544_at & Alpha integrin binding protein 63 \\
\hline 204607_at & 3-hydroxy-3-methylglutaryl-Coenzyme A synthase 2 \\
\hline 204760_s_at & Nuclear receptor subfamily 1 , group D, member 1 \\
\hline 204997_at & Glycerol-3-phosphate dehydrogenase 1 (soluble) \\
\hline 205073_at & $\begin{array}{l}\text { Cytochrome P450 subfamily IIJ(arachidonic acid } \\
\text { epoxygenase) pp } 2\end{array}$ \\
\hline 205749_at & $\begin{array}{l}\text { Cytochrome P450, subfamily I(aromatic compound- } \\
\text { inducible), pp } 1\end{array}$ \\
\hline 208308_s_at & Glucose phosphate isomerase \\
\hline 208684_at & Coatomer protein complex, subunit alpha \\
\hline 208998_at & Uncoupling protein 2 (mitochondrial, proton carrier) \\
\hline 209122_at & Adipose differentiation-related protein \\
\hline 209123_at & Quinoid dihydropteridine reductase \\
\hline 209355_s_at & Phosphatidic acid phosphatase type $2 \mathrm{~B}$ \\
\hline 209775_x_at & Solute carrier family 19 (folate transporter), member 1 \\
\hline 209776_s_at & Solute carrier family 19 (folate transporter), member 1 \\
\hline 209777_s_at & Solute carrier family 19 (folate transporter), 1 \\
\hline 209782_s_at & D site of albumin promoter binding protein \\
\hline 210095_s_at & Insulin-like growth factor binding protein 3 \\
\hline \multicolumn{2}{|l|}{ 210830_s_at } \\
\hline \multicolumn{2}{|l|}{ 211576_s_at } \\
\hline \multicolumn{2}{|l|}{ 211618_s_at } \\
\hline 211699_x_at & Hemoglobin, alpha 1 \\
\hline 211745_x_at & Hemoglobin, alpha 2 \\
\hline \multicolumn{2}{|l|}{ 211922_s_at } \\
\hline \multicolumn{2}{|l|}{ 213706_at } \\
\hline \multicolumn{2}{|l|}{ 213787_s_at } \\
\hline \multicolumn{2}{|l|}{ 214274_s_at } \\
\hline \multicolumn{2}{|l|}{ 216474_x_at } \\
\hline 216894_x_at & Cyclin-dependent kinase inhib. 1C (p57, Kip2) \\
\hline 217414_x_at & Hemoglobin, alpha 2 \\
\hline \multicolumn{2}{|l|}{ 217478_s_at } \\
\hline 218094_s_at & Chromosome 20 open reading frame 35 \\
\hline 218421_at & Hypothetical protein FLJ23239 \\
\hline 218688_at & DKFZP586B1621 protein \\
\hline 219398_at & Protein FLJ20871 similar to FSP27 \\
\hline 219534_x_at & Cyclin-dependent kinase inhib. 1C (p57, Kip2) \\
\hline 220070_at & Hypothetical protein FLJ13798 \\
\hline 221529_s_at & Plasmalemma vesicle associated protein \\
\hline 221552_at & Lipase protein \\
\hline 221679_s_at & Lipase protein \\
\hline \multicolumn{2}{|l|}{ 221951_at } \\
\hline 31637_s_at & Nuclear receptor subfamily 1 , group D, 1 \\
\hline 38158_at & Extra spindle poles, S. cerevisiae, homolog of \\
\hline 45288_at & Lipase protein \\
\hline 65630_at & Similar to RIKEN cDNA 5530601119 gene, \\
\hline 209777_ss_at & Solute carrier family 19 (folate transporter), 1 \\
\hline
\end{tabular}

Probe identification numbers (Probe IDs) refer to the Affymetrix reference number of the measured probe pairs.
Table 2. Gene reporters consistently upregulated by perfusion of a small intestinal segment with 80 and $400 \mathrm{mg}$ of iron on 2 separate test days

\begin{tabular}{ll}
\hline \hline \multicolumn{1}{c}{ Probe ID } & \multicolumn{1}{c}{ Gene Title } \\
\hline 201362_at & NS1-binding protein \\
201368_at & \\
201427_s_at & Selenoprotein P, plasma, 1 \\
201695_s_at & Nucleoside phosphorylase \\
201925_s_at & Decay accelerating factor for complement \\
203287_at & Ladinin 1 \\
203574_at & Nuclear factor, interleukin 3 regulated \\
203725_at & Growth arrest and DNA-damage-inducible, alpha \\
203824_at & Transmembrane 4 superfamily member 3 \\
203914_x_at & Hydroxyprostaglandin dehydro-genase 15-(NAD) \\
205769_at & Fatty-acid-Coenzyme A ligase, very long-chain 1 \\
205771_s_at & A kinase (PRKA) anchor protein 7 \\
205860_x_at & Folate hydrolase (prostate-specific membrane antigen) 1 \\
205969_at & Arylacetamide deacetylase (esterase) \\
208921_s_at & Sorcin \\
208949_s_at & Galectin 3 \\
209301_at & Carbonic anhydrase II \\
210177_at & Tripartite motif-containing 15 \\
211548_s_at & Hydroxyprostagland dehydrogenase 15NAD \\
211962_s_at & \\
212130_x_at & \\
213372_at & \\
215363_x_at & SIPL protein \\
217761_at & Glucosaminyl (N-acetyl) transferase 3 \\
219508_at & Hypothetical protein FLJ22800 \\
220639_at & KIAA0303 protein \\
222303_at & \\
40016_g_at & \\
\hline
\end{tabular}

profiles following the iron interventions (Table 4). The realtime PCR measurements on individual samples showed that the results from the pooled samples represented those of most individual samples (Table 5). For six of the selected genes, all individual results showed a unidirectional response to the iron challenges, which was in agreement with the results from the pooled samples. The real-time PCR data from one volunteer did not show the same direction of response to the iron challenges (gene NM_003355, pool 1, subject 1; Table 5) compared with the pooled samples.

Table 3. Processes in small intestinal mucosa affected by iron administration

\begin{tabular}{llc}
\hline \hline \multicolumn{1}{c}{ Process } & \multicolumn{1}{c}{ MAPP } & $\begin{array}{c}\text { Gene Reporters } \\
\text { Changed/Measured/Total }\end{array}$ \\
\hline Cell cycle & KEGG & $6 / 9 / 104$ \\
GPCRs, class C & GPCRDB Mapp & $3 / 12 / 18$ \\
Calcium channels & Local MAPPs & $7 / 22 / 28$ \\
Complement activation, & Local MAPPs & $4 / 12 / 16$ \\
$\quad$ classical pathway & Local MAPPs & $9 / 45 / 69$ \\
Peptide GPCRs & GPCRDB MAPP & $22 / 112 / 289$ \\
\hline
\end{tabular}

Processes most strongly mediated by the 2 iron interventions in both pools are identified by Mappfinder, as described in MATERIALS AND METHODS. The middle column shows which database was used for the identification of the biological pathway. The number of mediated gene reporters that changed more than 2.3-fold by both iron interventions in both pools, the total number of genes involved in each process and represented on the microarray chips (HG $\mathrm{U} 133 \mathrm{~A}$ ), and the total number of genes involved in each process as specified by the consecutive databases are listed in the right column. GPCR, G-proteincoupled receptor; MAPP, MicroArray pathway profiles. 
Table 4. Comparison of RT-PCR and microarray results

\begin{tabular}{llcccr}
\hline \hline $\begin{array}{c}\text { GenBank } \\
\text { Accession No. }\end{array}$ & & $1 \mathrm{~L}$ & $1 \mathrm{H}$ & $2 \mathrm{~L}$ & $2 \mathrm{H}$ \\
\hline $\mathrm{nm} \_005410$ & RT-PCR & 1.30 & 1.90 & 2.04 & 1.56 \\
& Microarray & 1.28 & 1.68 & 1.39 & 1.24 \\
$\mathrm{~nm} \_001924$ & RT-PCR & 1.68 & 2.92 & 2.56 & 2.44 \\
& Microarray & 1.62 & 1.76 & 1.69 & 1.98 \\
$\mathrm{~nm} \_002306$ & RT-PCR & 1.56 & 1.96 & 2.26 & 3.20 \\
& Microarray & 1.46 & 1.66 & 1.32 & 1.39 \\
$\mathrm{~nm} \_005118$ & RT-PCR & 7.06 & 13.53 & 8.32 & 11.80 \\
& Microarray & 2.12 & 2.05 & 2.29 & 1.95 \\
$\mathrm{~nm} \_000775$ & RT-PCR & -1.31 & -1.29 & -1.21 & -1.36 \\
& Microarray & -1.38 & -1.37 & -1.12 & -1.35 \\
$\mathrm{~nm} \_003355$ & RT-PCR & -1.29 & -1.17 & -1.41 & -1.44 \\
& Microarray & -1.28 & -1.18 & -1.36 & -1.62 \\
$\mathrm{~nm} \_003056$ & RT-PCR & -1.76 & -1.75 & -1.57 & -1.62 \\
& Microarray & -1.71 & -1.76 & -1.44 & -1.77 \\
\hline
\end{tabular}

RT-PCR analysis of selected genes and microarray data are from the same genes. Data are expressed as fold changes compared with baseline. The first column $(1 \mathrm{~L})$ shows the gene expression data from pool 1 after administration of the low dosage of iron compared with baseline; column $1 \mathrm{H}$ shows data from pool 1 after administration of the high iron dosage. $2 \mathrm{~L}$ and $2 \mathrm{H}$ columns show the data from pool 2 after administration of the low and high iron dosage, respectively.

\section{TBARS and TEAC}

To check steady-state conditions, TBARS and TEAC were measured at 30 and $15 \mathrm{~min}$ and immediately before iron perfusion was started. TBARS concentrations were $0.06,0.06$, and $0.20 \mu \mathrm{M}$, and TEAC values were 577,520 , and 597 at 30 , 15 , and $0 \mathrm{~min}$ before starting the $80-\mathrm{mg}$ iron perfusion, respectively. Before the 400-mg iron perfusions were started, the TBARS concentrations were $0.33,0.29$, and $0.40 \mu \mathrm{M}$ and the TEAC values were 822,819 , and $806 \mu \mathrm{M}$, respectively, at 30 , 5 , and 0 min before iron perfusion, showing that TBARS and TEAC values were, indeed, in a steady state.

The TBARS concentration in intestinal fluid samples after administration of $80 \mathrm{mg}$ of iron increased significantly from $0.2 \mu \mathrm{M}(\mathrm{SD} 0.16)$ at baseline to 2.9(SD1.2), 2.3(SD1.5), and $2.4 \mu \mathrm{M}(\mathrm{SD} 1.4)$ at 30,45 , and $60 \mathrm{~min}$, respectively, after the start of the iron perfusion $(P<0.0001)$. The TBARS concentration after administration of $400 \mathrm{mg}$ of iron increased significantly from $0.4 \mu \mathrm{M}(\mathrm{SD} 0.5)$ at baseline to 3.8(SD1.1),

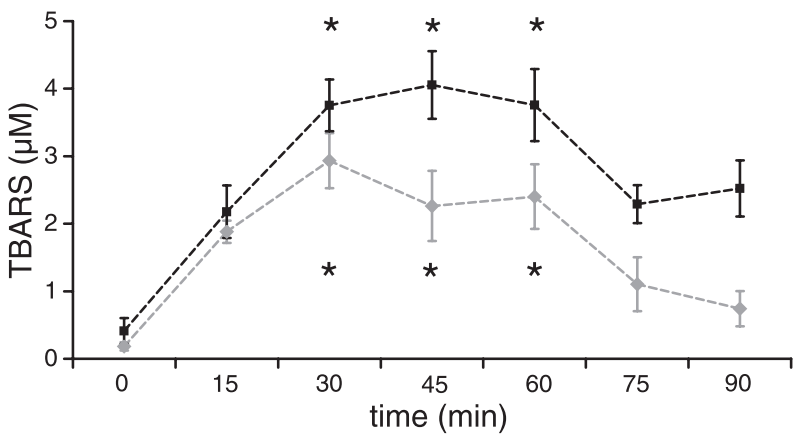

Fig. 1. Thiobarbituric acid-reactive substances (TBARS) concentrations, an indicator of lipid peroxidation, in intestinal perfusion samples collected over 15 -min intervals after perfusion of a $40-\mathrm{cm}$ segment in the proximal small intestine in 8 subjects. Baseline values at time $=0$ were obtained after $180 \mathrm{~min}$ of saline perfusion. Saline containing 80 (diamonds) or $400 \mathrm{mg}$ (squares) of elemental iron as ferrous gluconate was perfused for $30 \mathrm{~min}$, followed by saline perfusion for $60 \mathrm{~min}$ at $10 \mathrm{ml} / \mathrm{min}$. Values are means $\pm \mathrm{SE}$. *Significant differences compared with baseline $(P<0.001)$.

4.1(SD1.4), and $3.8 \mu \mathrm{M}(\mathrm{SD} 1.5)$ at 30,45 , and $60 \mathrm{~min}$ after the start of the iron perfusion $(P<0.001)$. Univariate ANOVA showed that TBARS production after administration of $400 \mathrm{mg}$ of iron was significantly higher compared with $80 \mathrm{mg}$ of iron $(P<0.001$; Fig. 1$)$.

The TEAC concentration after administration of $80 \mathrm{mg}$ of iron increased from $597 \mu \mathrm{M}(\mathrm{SD} 187)$ at baseline to 1,032 $\mu \mathrm{M}(\mathrm{SD609})$ at $30 \mathrm{~min}$ after the start of the iron perfusion. Statistical analysis did not detect an overall time effect. The TEAC concentration after administration of 400-mg iron intervention increased significantly from $806 \mu \mathrm{M}(\mathrm{SD} 293)$ at baseline to 1,889 (SD635) and $1,490 \mu \mathrm{M}$ (SD413) at 30 and 45 min, respectively, after the start of the iron perfusion $(P<$ $0.05)$.

Univariate ANOVA showed that TEAC after administration of $400 \mathrm{mg}$ of iron was significantly higher than after $80 \mathrm{mg}$ of iron $(P<0.001$; Fig. 2$)$.

\section{DISCUSSION}

In the present study, a recently developed intestinal perfusion protocol was combined with microarray technology to study nutrient-gut and nutrient-gene interactions in the human

Table 5. Comparison of pooled and individual RT-PCR results

\begin{tabular}{|c|c|c|c|c|c|c|c|}
\hline & NM_005410 & NM_001924 & NM_000775 & NM_002306 & NM_003056 & NM_005118 & NM_003355 \\
\hline L subject 1 & 1.49 & 2.52 & 0.93 & 1.39 & 0.62 & 13.79 & 1.85 \\
\hline H subject 1 & 2.39 & 1.85 & 1.02 & 0.73 & 0.30 & 10.73 & 1.97 \\
\hline H subject 2 & 2.04 & 3.55 & 0.82 & 3.03 & 0.28 & 21.71 & 0.67 \\
\hline L pool 2 & 2.04 & 2.56 & 0.79 & 2.26 & 0.43 & 8.32 & 0.59 \\
\hline L subject 3 & 2.30 & 1.52 & 0.67 & 1.21 & 0.15 & 6.23 & 0.55 \\
\hline H pool 2 & 1.56 & 2.44 & 0.64 & 3.20 & 0.38 & 11.80 & 0.56 \\
\hline H subject 1 & 2.08 & 1.87 & 0.53 & 1.19 & 0.25 & 15.43 & 0.63 \\
\hline H subject 2 & 1.28 & 2.29 & 0.93 & 3.72 & 0.35 & 5.71 & 0.86 \\
\hline H subject 3 & 1.03 & 1.31 & 0.69 & 1.31 & 0.19 & 8.22 & 0.39 \\
\hline
\end{tabular}

RT-PCR analysis of selected genes on pooled (pool 1 and pool 2, respectively) and individual samples from each subject. Data, which are normalized to GAPDH, are expressed as fold changes compared with baseline. L, changes in gene expression induced by administration of the low iron dosage; H, changes in gene expression induced by administration of the high iron dosage. 


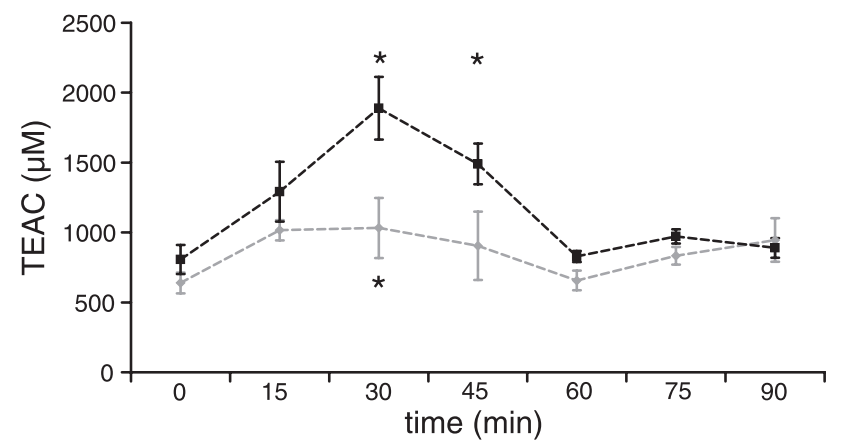

Fig. 2. Trolox-equivalent antioxidant capacity (TEAC) in intestinal perfusion samples collected over 15-min intervals after perfusion of a 40-cm segment in the proximal small intestine in 8 subjects. Baseline values at time $=0$ were obtained after $180 \mathrm{~min}$ of saline perfusion. Saline containing 80 (diamonds) or $400 \mathrm{mg}$ (squares) of elemental iron as ferrous gluconate was perfused for 30 $\mathrm{min}$, followed by saline perfusion for $60 \mathrm{~min}$ at $10 \mathrm{ml} / \mathrm{min}$. Values are means \pm SE. *Significant differences compared with baseline $(P<0.05)$.

small intestine to synchronously investigate several intestinal responses to luminal oxidative challenges provoked by different iron dosages. Acute exposure of the proximal small intestine to either a low or a high dosage of ferrous iron induced dose-dependent lipid peroxidation in the intestinal lumen and a synchronous increase in luminal antioxidant capacity. These parameters were measured in intestinal fluid samples from all eight volunteers, in contrast to the microarray analyses, which were done on the samples from five volunteers. The mean TBARS and TEAC values from all eight volunteers did not change in only the five volunteers that were included in the microarray measurements (data not shown). The acute, singledose, iron challenges mediated gene expression of a number of gene reporters. Both iron interventions strongly affected at least six distinct biological pathways on the transcriptional level.

We recently showed that perfusion of a $40-\mathrm{cm}$ duodenum segment with $80 \mathrm{mg}$ of iron as ferrous sulfate induced lipid peroxidation and the release of an unknown antioxidant. The rise in antioxidant capacity following iron ingestion was not caused by ex vivo TBARS formation during the analytical assay, cell lysis of epithelial cells, glutathione, uric acid, or vitamin $C$ and was of nonprotein origin (24). The present study, applying ferrous gluconate, confirmed the catalyzing effects of ferrous iron administration in the small intestine to induce oxidative damage and the release of antioxidants into the intestinal lumen. At baseline, during the initial saline perfusion, TBARS were only marginally present. After ingestion of either the low or the high iron dosage, TBARS concentrations increased in a dose-dependent manner. This increase was accompanied by a similar dose-dependent increase in TEAC. In the view of the highly diluted intestinal fluid with the saline solution used for perfusion of the intestinal segment, the TBARS and TEAC concentrations were very high; all samples consisted mainly of the in-going saline solution mixed with small amounts of intestinal secretions. This indicates that the iron administration resulted in powerful antioxidant responses. In an attempt to identify the origin of the antioxidant response, NMR spectra from samples with high and low antioxidant capacity were taken. Although differences between spectra were observed, it was not possible to identify the compound(s) responsible for these differences (data not shown).

The oligonucleotide microarray enabled one to simultaneously monitor the expression in vivo of more than 20,000 gene reporters. Among numerous processes that were slightly mediated by the iron interventions, six distinct processes were strongly regulated, as listed in Table 3. Three of these six processes involved GPCRs. However, two of these three processes were identified using the GPCRDB database, whereas one was identified by local MAPPS, as was described in METHODS. We cannot exclude that some gene reporters were attributed to one process in the GPCRDB database and at the same time to the GPCR process identified by local MAPPS, hence causing an overestimation of the genes involved in GPCR-associated processes. However, from the results, it is clear that GPCRs were strongly mediated by the iron interventions. GPCRs comprise the largest superfamily of proteins in the body. Ligands for these receptors are biogenic amines, peptides, glycoproteins, lipids, nucleotides, ions, and proteases. All GPCRs are able to recruit and regulate the activity of intracellular $G$ proteins, which regulate a large array of intracellular processes (13). The observation that GPCRs were regulated by iron-induced oxidative stress may indicate a yet unknown function of G-protein-associated processes in response to cellular stress. The observation that complement activation is regulated by the iron administrations suggests that the iron-induced oxidative damage triggered immune activation in the duodenal mucosa. Complement activation has previously been associated with mucosal damage in ulcerative colitis (25), whereas it was also established that mucosal damage owing to autologous complement activation can be prevented by endogenous regulatory mechanisms (2). Furthermore, it was shown that intestinal epithelial cells are able to produce components of complement activation and that this production can be mediated by cytokines in the intestinal epithelium (2). Increased activation of complement activation, as observed in the iron perfusion experiments, may induce complement-induced damage. Future studies will need to elucidate the consequences of complement activation in duodenal mucosa. The functional role of the cell cycle- and calcium channel-related processes, which were affected by the iron interventions, is not yet described to our knowledge and needs to be elucidated. Interestingly, it was shown that mice fed a low-selenium diet, which is a trace mineral with antioxidant properties, appeared to have an increased activation of genes involved in cell cycle control (18). This suggested that selenium mediates cell cycle control, which may account for its anti-tumorigenic properties. The present observation that cell cycle was mediated by iron-induced oxidative stress suggests that this process mediates the initiation of carcinogenesis if the oxidant/antioxidant balance is disturbed.

Genes involved in the regulation of iron absorption mechanisms have drawn the attention of many investigators, especially in the view of their causal role in the pathogenesis of hereditary hemochromatosis. Several proteins are involved in the direct regulation of iron uptake from the duodenal lumen. Divalent metal transporter 1 (DMT1), a transmembrane transporter for divalent metals, including ferrous iron, plays an important role in the absorption of iron from the gut lumen into enterocytes, whereas ferroportin 1 is a transmembrane iron exporter molecule involved in the basolateral iron transport 
from enterocytes into the circulation. In a recent study in mice (8), iron supplementation for $2 \mathrm{wk}$ downregulated the levels of transcripts of DMT1, ferroportin1, and transferrin receptor 1, whereas feeding an iron-deficient diet resulted in an increase of these transcripts. Furthermore, duodenal gene expression of an iron-responsive element splice variant of DMT1 was significantly downregulated $1 \mathrm{~h}$ after intragastric iron administration in rats (10). In the present study, we showed that the gene expression of DMT1 and transferrin receptor 1 tended to decrease by $\sim 25 \%$ in both sample pools following administration of the low and the high iron dosage into the duodenum, although these gene reporters were not regarded as significantly changed after statistical analysis. Unfortunately, ferroportin1 was not represented on the gene chip. Our findings contribute to the ongoing debate of the precise regulation of intestinal iron absorption. It is commonly acknowledged that high iron levels in the enterocytes downregulate DMT1 expression (10). The finding of the present study that acute iron ingestion may downregulate DMT1 and transferrin receptor 1 expression suggests that intestinal iron concentrations directly mediate transcription of these proteins, as was shown previously only for DMT1 expression $(10,29)$.

The genome-wide microarrays used yield information about the expression of a myriad of gene reporters. The major advantage of this technique is the ability to synchronously monitor many biological processes. However, the present study design has some drawbacks. The duodenal mucosal tissue samples comprised a variety of mucosal and submucosal cell types. Changes in gene expression that only occur in one cell type were, therefore, diluted by the presence of other cell types and, hence, may not have reached significance. In addition, gene expression levels differ between individuals. Pooling samples from different volunteers and the inclusion of only those gene reporters that were affected by both the low and the high iron dosage in both pools for further analysis, as was applied in the present investigation, reduced the effects of inter- and intra-individual variations in gene expression. We cannot exclude, however, that, using this approach, some relevant gene reporters that were mediated by the iron interventions were erroneously excluded from further analyses. On the other hand, the procedure followed to identify iron-mediated biological pathways ensured that the study results reveal the most important, strongest mediated processes.

Finally, the microarray assay itself could have induced false-positive signals due to cross-hybridization or nonspecific binding to the probe pairs. This seems highly unlikely in the view of previously published studies in which the data of Affymetrix microarray chips were successfully compared with real-time PCR analyses $(12,27)$. In the present study, we also confirmed the microarray data of seven genes that were mediated by the iron interventions with real-time PCR analyses. Table 4 shows that the changes in gene expression profiles in both pools after both iron interventions were roughly the same, either applying real-time PCR or microarray analyses. Some differences between the two methods were present, as can be observed from the results of gene nm_005118. Real-time PCR analysis showed a 13.53 -fold change in the expression of this gene reporter, whereas microarray analysis showed only a 2.05 -fold change in expression. This difference may be attributed to the low baseline level of this gene, which is a common concern in the interpretation of microarray results (12), espe- cially if results are expressed as fold change. Because all real-time PCR data show the same direction in changes in gene expression profiles, we assume that the microarray data provide valid gene expression profiles for all gene reporters. We investigated the effects of pooling different samples on the outcome of the gene expression analysis by running real-time PCR analyses on seven genes in all individual samples and subsequently comparing those results with the results from the pooled samples. We showed that the results from the pooled samples represented unidirectional changes in almost all cases. Only the real-time PCR data from one gene, measured in one volunteer, were not in agreement with the results observed in the pooled samples. Overall, the pooling strategy seemed a successful approach as representation of individual responses in most gene reporter analyses.

It was not possible to establish the functional consequences of the regulation of the processes identified in Table 3 . The impact of the iron interventions on gene expression profiles differed between the two pools, owing to biological, interindividual variation. Future studies to the functional consequences of changes in the gene expression profiles, as identified in this study, will have to be designed to determine the biological impact of the present study.

This study showed that iron administration in the human small intestine induced lipid peroxidation, and a rise in antioxidant capacity of the small intestinal secretions, in a dosedependent fashion. Both iron dosages mediated the expression of many gene reporters, indicating that the novel approach to study nutrient-gut interactions was successful to detect many transcriptional changes. Hence, the applied technique offers a unique method to study effects of a single dietary component on transcriptome profiles in healthy individuals as well as in patients. Besides considerable inter- and intra-individual differences in gene expression profiles, we identified six processes that appeared to be strongly and consistently regulated by iron administration or iron-induced oxidative stress in the small intestine. Further studies are needed to establish the functional consequences of acute and chronic iron administration and oxidative stress in the human small intestine.

\section{GRANTS}

This study was supported by the European Union (QLK1-CT-1999-00337).

\section{REFERENCES}

1. Aghdassi E, Carrier J, Cullen J, Tischler M, and Allard JP. Effect of iron supplementation on oxidative stress and intestinal inflammation in rats with acute colitis. Dig Dis Sci 46: 1088-1094, 2001.

2. Andoh A, Fujiyama Y, Bamba T, and Hosoda S. Differential cytokine regulation of complement $\mathrm{C} 3, \mathrm{C} 4$, and factor $\mathrm{B}$ synthesis in human intestinal epithelial cell line, Caco-2. J Immunol 151: 4239-4247, 1993.

3. Berg van den R, Haenen G, van den Berg H, and Bast A. Applicability of an improved Trolox equivalent antioxidant capacity (TEAC) assay for evaluation of antioxidant capacity measurements of mixtures. Food Chemistry: 511-517, 1999.

4. Birkenkamp-Demtroder K, Christensen LL, Olesen SH, Frederiksen CM, Laiho P, Aaltonen LA, Laurberg S, Sorensen FB, Hagemann R, and ORntoft TF. Gene expression in colorectal cancer. Cancer Res 62: 4352-4363, 2002.

5. Boeckmann B, Bairoch A, Apweiler R, Blatter MC, Estreicher A, Gasteiger E, Martin MJ, Michoud K, O'Donovan C, Phan I, Pilbout $\mathbf{S}$, and Schneider M. The SWISS-PROT protein knowledgebase and its supplement TrEMBL in 2003. Nucleic Acids Res 31: 365-370, 2003.

6. Consortium TGO. Creating the gene ontology resource: design and implementation. Genome Res 11: 1425-1433, 2001. 
7. Dahlquist KD, Salomonis N, Vranizan K, Lawlor SC, and Conklin BR. GenMAPP, a new tool for viewing and analyzing microarray data on biological pathways. Nat Genet 31: 19-20, 2002.

8. Dupic F, Fruchon S, Bensaid M, Loreal O, Brissot P, Borot N, Roth MP, and Coppin H. Duodenal mRNA expression of iron related genes in response to iron loading and iron deficiency in four strains of mice. Gut 51: $648-653,2002$.

9. Fodor I and Marx JJ. Lipid peroxidation of rabbit small intestinal microvillus membrane vesicles by iron complexes. Biochim Biophys Acta 961: 96-102, 1988

10. Frazer DM, Wilkins SJ, Becker EM, Murphy TL, Vulpe CD, McKie AT, and Anderson GJ. A rapid decrease in the expression of DMT1 and Dcytb but not Ireg1 or hephaestin explains the mucosal block phenomenon of iron absorption. Gut 52: 340-346, 2003.

11. Geerling BJ, Badart-Smook A, Stockbrügger RW, and Brummer RJ. Comprehensive nutritional status in patients with long-standing Crohn disease currently in remission. Am J Clin Nutr 67: 919-926, 1998.

12. Gerhold D, Lu M, Xu J, Austin C, Caskey CT, and Rushmore T. Monitoring expression of genes involved in drug metabolism and toxicology using DNA microarrays. Physiol Genomics 5: 161-170, 2001.

13. Gether U. Uncovering molecular mechanisms involved in activation of $G$ protein-coupled receptors. Endocr Rev 21: 90-113, 2000

14. Gonzalez PK, Doctrow SR, Malfroy B, and Fink MP. Role of oxidant stress and iron delocalization in acidosis-induced intestinal epithelial hyperpermeability. Shock 8: 108-114, 1997.

15. Lih-Brody L, Powell SR, Collier KP, Reddy GM, Cerchia R, Kahn E, Weissman GS, Katz S, Floyd RA, McKinley MJ, Fisher SE, and Mullin GE. Increased oxidative stress and decreased antioxidant defenses in mucosa of inflammatory bowel disease. Dig Dis Sci 41: 2078-2086, 1996.

16. Marx JJ and van Asbeck BS. Use of iron chelators in preventing hydroxyl radical damage: adult respiratory distress syndrome as an experimental model for the pathophysiology and treatment of oxygen-radicalmediated tissue damage. Acta Haematol 95: 49-62, 1996.

17. Odetti P, Valentini S, Aragno I, Garibaldi S, Pronzato MA, Rolandi E, and Barreca T. Oxidative stress in subjects affected by celiac disease. Free Radic Res 29: 17-24, 1998.

18. Rao L, Puschner B, and Prolla TA. Gene expression profiling of low selenium status in the mouse intestine: transcriptional activation of genes linked to DNA damage, cell cycle control and oxidative stress. J Nutr 131: 3175-3181, 2001

19. Reifen R, Matas Z, Zeidel L, Berkovitch Z, and Bujanover Y. Iron supplementation may aggravate inflammatory status of colitis in a rat model. Dig Dis Sci 45: 394-397, 2000.

20. Siegers CP, Bumann D, Trepkau HD, Schadwinkel B, and Baretton G. Influence of dietary iron overload on cell proliferation and intestinal tumorigenesis in mice. Cancer Lett 65: 245-249, 1992.

21. Srigiridhar K and Nair KM. Iron-deficient intestine is more susceptible to peroxidative damage during iron supplementation in rats. Free Radic Biol Med 25: 660-665, 1998

22. Srigiridhar K, Nair KM, Subramanian R, and Singotamu L. Oral repletion of iron induces free radical mediated alterations in the gastrointestinal tract of rat. Mol Cell Biochem 219: 91-98, 2001.

23. Thykjaer T, Workman C, Kruhøffer M, Demtröder K, Wolf $\mathbf{H}$, Andersen LD, Frederiksen CM, Knudsen S, and Ørntoft TF. Identification of gene expression patterns in superficial and invasive human bladder cancer. Cancer Res 61: 2492-2499, 2001.

24. Troost F, Saris W, Haenen G, Bast A, and Brummer RJ. A new method to study oxidative damage and antioxidants in the human small bowel: effects of iron application. Am J Physiol Gastrointest Liver Physiol 285: G354-G359, 2003.

25. Ueki T, Mizuno M, Uesu T, Kiso T, Nasu J, Inaba T, Kihara Y, Matsuoka Y, Okada H, Fujita T, and Tsuji T. Distribution of activated complement, $\mathrm{C} 3 \mathrm{~b}$, and its degraded fragments, $\mathrm{iC} 3 \mathrm{~b} / \mathrm{C} 3 \mathrm{dg}$, in the colonic mucosa of ulcerative colitis (UC). Clin Exp Immunol 104: 286-292, 1996.

26. Wurzelmann JI, Silver A, Schreinemachers DM, Sandler RS, and Everson RB. Iron intake and the risk of colorectal cancer. Cancer Epidemiol Biomarkers Prev 5: 503-507, 1996.

27. Xiao J, Gregersen S, Kruhøffer M, Pedersen SB, Ørntoft TF, and Hermansen $\mathbf{K}$. The effect of chronic exposure to fatty acids on gene expression in clonal insulin-producing cells: studies using high density oligonucleotide microarray. Endocrinology 142: 4777-4784, 2001.

28. Yamada T and Grisham MB. Role of neutrophil-derived oxidants in the pathogenesis of intestinal inflammation. Klin Wochenschr 69: 988-994, 1991.

29. Zoller H, Koch RO, Theurl I, Obrist P, Pietrangelo A, Montosi G, Haile DJ, Vogel W, and Weiss G. Expression of the duodenal iron transporters divalent-metal transporter 1 and ferroportin 1 in iron deficiency and iron overload. Gastroenterology 120: 1412-1419, 2001 